\title{
Assessment of visual health campaign activities at schools - teachers' perception
}

\author{
A valiaçãode atividadesdecampanha de saúdeocularna escola - \\ percepçãodeprofessores
}

\author{
Regina de Souza Carvalho ${ }^{1}$ \\ Edméa Rita Temporini ${ }^{2}$ \\ Newton Kara-José ${ }^{3}$
}

Trabalho realizado no Departamento de Oftalmologia da Faculdade de Medicina da Universidade de São Paulo - USP - São Paulo (SP) - Brazil.

${ }^{1}$ Pedagogue, Post-graduation student in Ophthalmology, Universidade de São Paulo - USP - São Paulo (SP) - Brazil.

${ }^{2}$ Associate Professor, Research Assistant to the Ophthalmology Department at the USP - São Paulo (SP) Brazil and at the Universidade de Campinas - UNICAMP - Campinas (SP) - Brazil.

${ }^{3}$ Head Professor of Ophthalmology at the USP - São Paulo (SP) - Brazil and at the UNICAMP - Campinas (SP) - Brazil.

Address for correspondence: Rua Barão do Triunfo, 1220 - Apto 122 - São Paulo (SP) CEP 04602-005

E-mail: rcso@uol.com.br

Recebido para publicação em 28.05.2006

Aprovado em 30.11.2006

Nota Editorial: Depois de concluída a análise do artigo sob sigilo editorial e com a anuência do Dr. Marinho Jorge Scarpi sobre a divulgação de seu nome como revisor, agradecemos sua participação neste processo.

\begin{tabular}{l} 
ABSTRACT \\
\hline Purpose: 1) To assess the opinion of teachers involved in visual screening \\
of school-age children and their referral to ophthalmologic examination \\
within the "Eye-to-Eye National Campaign for Visual Disorders Prevention \\
and Rehabilitation" (Campanha Nacional de Prevenção e Reabilitação \\
Visual Olho no Olho); 2) To identify the teachers' perception with respect \\
to the training received for conducting the campaign. Methods: A descrip- \\
tive study has been conducted, based on data recorded from the application \\
of a questionnaire to 1,517 elementary school teachers working in public \\
schools in 27 Brazilian states. The following items were examined: received \\
orientation, use of educational videos and handbooks, supplied explana- \\
tions, difficulties, questions and overall campaign assessment. Results: \\
82.0\% of the teachers stated they had received orientation and $92.0 \%$ \\
stated they had read the “Teacher Orientation Manual". Among those who \\
received orientation, $47.0 \%$ stated it had been supplied by school officials; \\
30.0\%, by healthcare agents, and $23.0 \%$ by ophthalmologists. In the self- \\
assessment of performance, $58.0 \%$ reported no difficulties; $32.0 \%$ reported \\
questions concerning the campaign activities and the professionals who \\
most frequently asked to provide clarification were those from the State \\
Education Agency (38.0\%), followed by the school director ( $20.0 \%$ ). \\
Conclusions: Most teachers considered themselves adequately trained \\
and oriented to take part in the campaign. Teachers' training was provided \\
by administrative officials, previously trained by ophthalmologists ("mul- \\
tiplying effect") and the small percentage of questions raised indicated the \\
validity of the procedure. Concerns have been raised as to the information \\
about the ophthalmologic examination, transportation of the children and \\
delivery of glasses. This kind of programalways presents some difficulties \\
and requires adjustments. It should, indeed, be improved, perhaps through \\
acloserinvolvement of the community and families during its development.
\end{tabular}

Keywords: Ocular health; School health; School health services; Health promotion; Health education; Health knowledge, attitudes, practice; Eye diseases/diagnosis; Eye diseases/ prevention \& control; Refractive errors/diagnosis

\section{INTRODUCTION}

For many decades, both public school educators and clinical ophthalmologists have been concerned about visual difficulties in school-age children. As early as in 1938, in Brazil, the prevention of childhood blindness aimed primarily at fighting ophthalmia neonatorum and at preventing trachoma, smallpox and hereditary syphilis ${ }^{(1)}$.

In that same year, the fight against trachoma received an important 
contribution from teachers, who transmitted to the children and the community information about habits and attitudes required for the maintenance of ocular health ${ }^{(2)}$.

Continued visual screening and ophthalmologic assistance programs, developed in partnership by healthcare and education agencies, started in the 1950's in the state of São Paulo ${ }^{(3-4)}$.

In the year 1970, the "School-age Child Care Plan" started to be developed (P. O S. E.) being subsequently implemented in 1973, 1974, and 1975. During this period, 2,981,276 children in the 1st grade of elementary school underwent visual screening conducted by teachers (93.19\% of the program's target group of children) and 399,647 were referred to ophthalmologic examination ${ }^{(4)}$.

From 1976 on, the P. O S. E. was included in the routine procedures of the State Healthcare Agency, but its implementation has been gradually reduced and is currently limited to some isolated initiatives in a few cities. The projects have been conducted in an uncoordinated fashion, by city governmental agencies, associated ophthalmologists, communities and NGOs.

The "Eye-to-Eye National Campaign for Visual Disorders Prevention and Rehabilitation" (Campanha Nacional de Prevenção e Reabilitação Visual Olho no Olho), implemented initially in 1998 as a systematic approach to care, is conducted through a joint effort of the Brazilian Council of Ophthalmology (CBO), the Education Ministry (FNDE), ophthalmologists from different regions of Brazil, teachers from the public school system (State and City levels) and volunteers, and covers the children regularly attending the 1st grade of elementary school in the public education network (State and City levels) $)^{(5)}$.

For the orientation of teachers concerning visual screening, observation of signs and symptoms of low vision, completion of forms, and referral to ophthalmologic consultation, a "Teacher Orientation Manual" has been developed, together with VHS tapes showing, step-by-step, the measurement of visual acuity and lectures delivered by ophthalmologists; and the "School Kid Good Vision Manual" containing orientation on ocular disorders (strabismus, amblyopia, blepharitis, conjunctivitis and eye care) was also supplied to the children's parents ${ }^{(6-7)}$. Over the three years since the initial implementation of the program, 10.5 million copies of the "School Kid Good Vision Manual" have been distributed ${ }^{(7)}$.

The "Eye to Eye" campaign took place, on national scale, in the years 1998, 1999, 2000, and 2001, covering, in this last year, 658 city areas, $3,011,442$ children of the 1 st grade elementary school; 91,000 teachers, 2,600 ophthalmologists; 368,844 school-age children referred to ophthalmologic examination; 177,284 visits, and 73,775 pairs of glasses prescribed and distributed $^{(8)}$.

Based on the P. O S. E. model, the visual screening of the children was performed primarily by teachers, because, in addition to their closer involvement with the children, they also serve as a link between the children's parents and the ophthalmologists, and are also responsible for disseminating information on visual health in the community related to the $\operatorname{school}^{(4)}$.
The present survey had two objectives: to check the opinion and perceptions of the involved teachers and the scheduling of activities of the "Eye-to-Eye" /2001 Campaign.

\section{METHODS}

A descriptive study was conducted, concerning the activities of the "Eye-to-Eye National Campaign for Visual Conditions Prevention and Rehabilitation"/2001. The answers recorded from the application of questionnaires completed by the involved teachers were analyzed.

A semi-structured questionnaire was sent, by mail, to 3,000 teachers, randomly selected from the 91,000 working in the public network of elementary schools. The teachers' participation was voluntary and the answers have been kept strictly confidential. All teachers received a postage-paid envelope with instructions for sending the completed questionnaire back to the CBO. The sample included 1,517 teachers who answered the questionnaire, distributed in 27 Brazilian states.

The following variates were assessed: orientation received about the campaign, people responsible for supplying orientation, use and understanding of the manuals and video tapes, difficulties, questions and overall campaign assessment. The questionnaire included multiple choice and discursive questions. Non-structured questions were used to assess difficulties, questions raised during the campaign and for the overall assessment.

For data presentation, as this was a self-applied questionnaire, the "n" on the tables showed some variation, due to the returned answers.

\section{RESULTS}

Of the 3,000 sent out questionnaires, 1,517 (50.6\%) were returned completed.

Table 1 shows the teachers' perceptions concerning orientation received. Among the 1,517 teachers, $82.0 \%$ stated they had received orientation and $92.0 \%$ stated they had read the "Teacher Orientation Manual". The "School Kid Good Vision Manual" was read by $92 \%$ of the teachers, while $63.0 \%$ said they had seen the explanatory video tapes.

As for the teachers' perceptions about the orientation on "school-age children visual acuity measurement", $67.0 \%$ confirmed having been oriented; $47.0 \%$ indicated school officials as those responsible for this orientation; healthcare agents were mentioned by $30.0 \%$, and ophthalmologists were mentioned by $23.0 \%$ as supplying orientation (Table 2).

Concerning difficulties found during the campaign, 58.0\% did not find difficulties whereas $42.0 \%$ did.

Teachers reported a lot of difficulties to schedule visits, providing transportation for the children to be examined, delays to receive the glasses and lack of interest on part of the parents. They reported reasonable difficulty concerning the teacher's availability, lack of information about the campaign, 
commitment by State Healthcare and Education Agencies and support from the ophthalmologists for the teachers' training. They mentioned few difficulties with: facilities for visual screening, lack of interest by the child in the screening and in the use of glasses, the screening procedure carried out by the teacher, the completion of forms and the displacement between different cities (Table 3 ).

Table 4 shows the questions raised by the teachers concerning the Campaign activities. Among those who mentioned having raised questions $(32.0 \%)$, such questions were stratified as: a lot of questions, average number of questions and few questions.

No mentions were recorded concerning a lot of questions on the activities to be performed during the campaign. The teachers reported an average number of questions concerning the performance of the visual acuity test (VAT) and a few questions concerning the result of the obtained visual acuity test and the completion of the forms. Of the 480 teachers who mentioned having questions, most (38.0\%) reported having searched for help from the State Education Agency officials, followed by the school director $(20.0 \%)$, the State Healthcare Agency officials (19.0\%), other school officials $(9.0 \%)$, ophthalmologists $(5.0 \%)$, the CBO $(3.0 \%)$, and others $(4.0 \%) ; 2.0 \%$ said they did not look for help to answer to their questions.

Chart 1 shows the assessment of the campaign by the teachers, including positive aspects (identification of schoolage children with deficiency and helping these children to improve their learning process, availability of free examination for poor children, incentive to permanence of the children in the school avoiding early dropouts, improved school performance of children with visual difficulties) and negative aspects (delayed start of the campaign activities, lack of efficient distribution of glasses, assistance limited to 1st graders, in- sufficient commitment by ophthalmologists and state agencies, delay in scheduling examinations, lack of efficient referral of the more severe cases, and lack of technical supervision).

\section{DISCUSSION}

A successful project in the area of Ophthalmology should take into account some basic assumptions: the target population's access to basic notions on prevention; availability of the offered services - screening, optical correction; compliance with the proposed treatment - surgery, optical correction, medication, return visits; participation of ophthalmologists in

\begin{tabular}{|c|c|c|}
\hline Perceptions on orientation $(n=1,517)$ & Yes (\%) & No $(\%)$ \\
\hline Orientation received & 82.0 & 18.0 \\
\hline Reading the "Teachers Orientation Manual" & 92.0 & 8.0 \\
\hline Reading the "School Kid Good Vision Manual" & 92.0 & 8.0 \\
\hline Watching explanatory videos & 63.0 & 37.0 \\
\hline
\end{tabular}

\begin{tabular}{|lcc|}
$\begin{array}{l}\text { Table 2. Orientation received on measurement of visual acuity (VA) } \\
\text { of children. Perception of teachers - } 1^{\text {st }} \text { grade elementary school } \\
\text { of public schools, in } 27 \\
\text { Brazilian states (\%) }\end{array}$ \\
$\begin{array}{l}\text { Perceptions regarding } \\
\text { orientation on VA }\end{array}$ & \multicolumn{2}{c}{$(\mathbf{n = 1 , 5 1 7 )}$} \\
\cline { 2 - 3 } $\begin{array}{l}\text { Measuring visual acuity } \\
\text { Person in charge }\end{array}$ & 67.0 & No (\%) \\
$\begin{array}{l}\text { School admin. official } \\
\text { Ophthalmologist }\end{array}$ & 47.0 & 33.0 \\
Healthcare agent & 23.0 & \\
& 30.0 & \\
\hline
\end{tabular}

\begin{tabular}{|c|c|c|c|}
\hline Perception $(n=1,517)$ & f & & $\%$ \\
\hline No difficulties found & 880 & & 58.0 \\
\hline Difficulties found & 637 & & 42.0 \\
\hline Aspects mentioned $(n=637)$ & $\begin{array}{c}\text { A lot of } \\
\text { difficulties }\end{array}$ & $\begin{array}{c}\text { Reasonable } \\
\text { difficulties }\end{array}$ & $\begin{array}{c}\text { Few } \\
\text { difficulties }\end{array}$ \\
\hline Scheduling examinations & $\mathbf{x}$ & & \\
\hline Locomotion/ transportation to exam site & $\mathbf{x}$ & & \\
\hline Delay to receive glasses & $\mathbf{x}$ & & \\
\hline Lack of interest by the parents & $\mathbf{x}$ & & \\
\hline Teacher's availability & & $\mathbf{x}$ & \\
\hline Lack of information & & $\mathbf{x}$ & \\
\hline Commitment by Healthcare and Education governmental agencies & & $\mathbf{x}$ & \\
\hline Support of ophthalmologist for training & & $\mathbf{x}$ & \\
\hline Facilities for visual screening & & & $\mathbf{x}$ \\
\hline Lack of interest by the child in screening and use of glasses & & & $\mathbf{x}$ \\
\hline Assessment of screening & & & $\mathbf{x}$ \\
\hline Completion of forms & & & $\mathbf{x}$ \\
\hline Displacement to other city & & & $\mathbf{x}$ \\
\hline
\end{tabular}


all the phases of the project; participation of volunteers, community, NGOs and healthcare authorities (partnerships); in addition, some conditions should be implemented in order to make the project become permanent ${ }^{(9-10)}$.

The Eye to Eye Campaign has been directed towards the accomplishment of all these goals, the only point missing being the assurance of continuity.

Teachers and school administration personnel have a positive influence on the educational process and may help in the different phases of the project, from locomotion and transportation of the poor population to direct forms of help, such as creating appropriate working conditions for the local ophthalmologists.

At school, the teacher is the core element for the identifica-

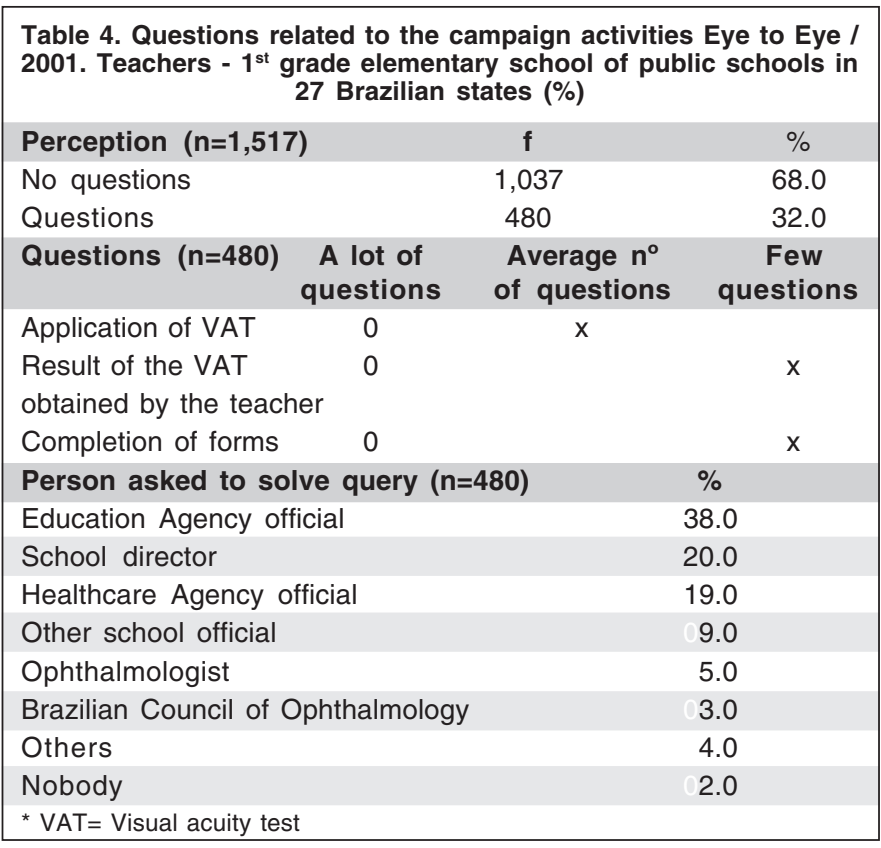

Chart 1. Assessment of the Eye to Eye campaign. Teachers - 1st grade elementary school of public schools in 27 Brazilian states (qualitative aspects)

\section{Positive aspects:}

Detection of school-age children with visual difficulties

Contribution to the learning process

Free examination available for poor children

Incentive to child's permanence in school and fewer dropouts

Improved school performance of children with visual difficulties

Negative aspects:

Delay in the start of campaign activities

Delay in delivery of glasses

Assistance limited to 1st grade school-age children

Little commitment by ophthalmologists and Healthcare and Education Agencies

Delay in scheduling consultations

Inefficient referral of more severe cases

Lack of technical supervision tion of children with signs, symptoms and behavioral patterns that suggest refractive errors and other visual disorders ${ }^{(4,10-11)}$.

In a survey with parents and school-age children during the "Veja Bem Brasil" Campaign 1998, reported that the teacher was the person who most often perceived the child's visual impairment $(70.6 \%)$, followed by the parents $(18.9 \%)$ and by the child itself $(7.9 \%)^{(12)}$.

Teachers are also responsible for the transmission of the obtained information on visual health to the school-based community. We may say that the teacher is one of the key elements for the successful implementation of the campaign, and should, therefore, be adequately oriented and trained for the execution of the required tasks. In this survey, most of the teachers $(82.0 \%)$ reported having been "oriented" about the campaign; only $18.0 \%$ reported not having received any orientation (Table 1).

In an other survey including the personnel working in the public education network of the city of Curitiba, PR, during the Eye to Eye Campaign/2000, showed that, among teachers, $85.9 \%$ of the responders considered the received orientation as "good" and/or "very good"(13).

The search for mechanisms that facilitate the understanding of the project by the teacher is one of the key issues for the success of the campaign.

Educational materials, such as booklets and illustrative video tapes, should be supplied to the teacher, to help appropriate assimilation of concepts.

For the Eye to Eye Campaigns, two manuals have been developed and delivered to the teachers, together with a VHS tape explaining how to perform the visual screening: the "Teacher Orientation Manual"(6) and the "School Kid Good Vision Manual" (7,10).

These manuals, handed to each target teacher and target child were read by most of the teachers $(92.0 \%)$, which confirmed the aroused interest and that these were excellent means for transmitting information, and should justifiably be available in future campaigns. The VHS tapes delivered to schools were watched by $63.0 \%$ of responders. As they require a TV set, which is not available in many schools, the $37.0 \%$ of teachers who did not see the tapes are justified (Table 1).

Two of the key tasks performed by teachers during the campaigns are the measurement of the children's visual acuity and the observation of attitudes that reveal visual impairment.

In the 2001 campaign, 368,844 school-age children were referred to ophthalmologic examination; 177,284 have been examined and 73,775 corrective glasses were prescribed ${ }^{(8)}$. One might argue against the validity of the visual acuity test performed by the teacher, since of 177,284 school-age children referred to ophthalmologic examination, only 73,775 needed corrective lenses.

It is understandable that teachers refer children who do not require correction, and the reasons for that are overestimation of risk, the intention to take advantage of this unique opportunity of having the child examined, or feelings of uncertainty about the test result ${ }^{(12)}$.

Teachers should receive continuous recycling on this mat- 
ter, focused on the visual acuity measurement and the different types of behavior presented by children during the test, i.e., simulation, inattention and shyness ${ }^{(14)}$.

Visual screening is more effective when all those involved receive adequate training and are highly motivated.

In a survey the authors ${ }^{(14)}$ reported a high percentage of correct procedures (more than $80 \%$ ) performed by adequately trained teachers, confirming that "it is highly recommended to have the visual acuity test in school-age children performed by trained teachers".

The training could take place at the school itself, under the supervision of the ophthalmologist, but this would require a much higher number of ophthalmologists and extended financial support ${ }^{(15)}$.

There is consensus about the notion that visual screening to detect possible deviations in visual function should be performed by adequately trained lay people ${ }^{(10)}$.

Table 2 shows that training and orientation on the measurement of visual acuity in school-age children have been primarily delivered by a "school official" (47.0\%) whereas $23.0 \%$ reported to have received training and orientation directly from the ophthalmologist. The trained teacher has performed the task correctly, since when asked about "questions raised concerning the campaign activities", $68.0 \%$ said they had raised no questions (Table 4). A similar result was found by a survey ${ }^{(13)}$ which reported that $57.5 \%$ of the teachers considered the orientation received from a non-ophthalmologist as good, whereas $59.3 \%$ thought it important to obtain better training and orientation on how to proceed in terms of referral and action to be taken in cases requiring treatment.

The professionals most often chosen to solve the teachers' queries about the campaign were those working at the State Education Agency (38.0\%), followed by school directors $(20.0 \%)$ and State Healthcare Agency officials (19.0\%). Ophthalmologists were looked for by only $5.0 \%$ of the teachers, since they were not always available or because the educators had the needed answers (Table 4).

As for the item "difficulties found during the campaign", some teachers mentioned again the lack of "support" by ophthalmologists, concerning training of the measurement of visual acuity (Table 3 ).

In 2002, in the state of São Paulo, the "Visual Habilitation Project" has been implemented in a joint effort of the São Paulo State Healthcare Agency (SES) and the São Paulo State Education Agency (SEE), including ophthalmologists, teachers, and volunteers. The project was supported by the Fundação Faculdade de Medicina / USP (FFM); Logistics $\mathrm{CBO}^{(10)}$. It was conducted in 509 city areas with less than 40,000 inhabitants each, in the state of São Paulo, and took 10 months to be completed, covering 111,500 school-age children in the 1st grade of the public network of elementary schools ${ }^{(10)}$. In this project, visual screening has also been performed by teachers, trained by non-medical professionals, called "multiplying agents", who, in turn, had been trained by ophthalmologists ("cascade effect"). The task of these agents was to give instructions and solve questions raised by the teachers concerning the visual acuity measurement, the completion of forms and the referral to ophthalmologists. The idea was to develop qualified trainers, with a theoretical and practical course being given to the agents by ophthalmologists.

The way the project was organized produced a "cascade effect", with the development of agents capable of orientating teachers.

The idea of introducing multiplying agents in the project, to orientate and train the teachers, is not a new one. In 1988, the Department of Assistance to the School-age Child (DAE) a governmental agency in the state of São Paulo - conducted healthcare orientation programs to train the teacher, and for that purpose the position of Coordinator of Assistance to the School-age Child (OAE) was created, representing a multiplying agent in charge of disseminating the information on healthcare at the school level ${ }^{(16)}$.

This procedure may be very useful to broaden the assistance to teachers, improve the standard of care and further reduce the questions raised about the campaign.

Among the "difficulties mentioned by teachers as occurring during the campaign" we found "transportation (locomotion)" of the children to the site of ophthalmologic examination, an item rated as "very difficult" (Table 3).

In a survey the authors ${ }^{(17)}$ reported cost constraints to take the child and its parent to the site of the examination as one of the important causes of absence, despite the fact that the examination was free.

Another survey ${ }^{(12)}$ found similar results, with $41.6 \%$ reporting the cost of the bus tickets for the parents, the child and its brothers or sisters who had to be taken along as the major difficulty to accomplish the ophthalmologic examination during the "Veja Bem Brasil" campaign, conducted at the University of São Paulo Medical School General Hospital in 1998.

In another study "Socioeconomic aspects influencing the absence of school-age children with visual disorders from the ophthalmologic examination", the authors ${ }^{(18)}$ found $15.2 \%$ of parents or tutors of school-age children reporting "transportation issues" as the reason for not taking the child to the scheduled ophthalmologic examination. However, $22.2 \%$ reported that the reason for absence was the fact that the child had already been taken to a visit with another ophthalmologist (healthcare insurance coverage).

Other causes for the absence of the child from the site of the examination were added ${ }^{(17)}$ :

- Lack of awareness of the importance of the ophthalmologic examination

- Denial of the child's low vision

- Illness - of the child or in the family

- Lack of interest by the parents

- Lack of information concerning the scheduled examination

Concerning the scheduling of the examination, teachers have also reported it as a "very difficult" issue (Table 3 ).

This procedure must be improved through reduction of the 
time between the screening and the ophthalmologic examination. In addition, the information about scheduled dates must reach teachers and children / parents in due time, so that families get prepared for the visit. In the projects conducted in the city area of São Paulo, screening, ophthalmologic examination and distribution of glasses were all completed over a period of a few months, showing great improvement, from the logistics perspective, over previous projects ${ }^{(10)}$.

In 2001, the CBO presented some suggestions for change, so that the Eye to Eye Campaign could fix some critical points. One of these points referred to the fact that some glass manufacturers, working under contract for the Education Ministry, did not deliver the glasses in due time to the children who needed them. As a solution for future campaigns, the $\mathrm{CBO}$ suggested contracting local manufacturers ${ }^{(10)}$.

Table 3 and chart 1 show that the teachers consider as another "very difficult" issue the delay in delivering the glasses. On the other hand, some authors ${ }^{(17)}$ found that $65.77 \%$ of the responders reported "no delay in the delivery of glasses in the Eye to Eye Campaign/2000, in the city of Maceió (AL)".

During the same campaign, both in the state and in the city of São Paulo, the glasses were delivered within less than six months after the ophthalmologic examination. In both cases, the higher level of efficiency was due to contracts with local manufacturers for the supply of glasses. In São Paulo, an agreement with FEDEX (courier) has contributed to speed up the delivery of glasses, despite the difficulties inherent to the distances to be covered in this huge city.

Regional variations in the time to deliver glasses have impaired the acceptance and the results of the campaign. In several places, the glasses were only available in the next school year. This was due to bureaucratic constraints in the Education Ministry, and to the selection of lens manufacturers that had to supply the whole country ${ }^{(10)}$.

Based on the analysis of the literature, several authors have stressed the critical importance of teachers, but no practical measure to acknowledge their contribution has been taken. We should not forget that the teacher's visual acuity is an important element in the performance of his/her tasks as an educator, and therefore the teacher should also benefit from these campaigns.

\section{CONCLUSIONS}

1) Most teachers considered they had received appropriate orientation. Most of them had read the supplied manuals and watched the video tapes, demonstrating the importance and the interest aroused by these training tools.

2) A large number of teachers was oriented and trained by administration officials, themselves trained by ophthalmologists. The fact that most of the teachers had no questions during the campaign indicates the effectiveness of the training and orientation of teachers by non-medical professionals (multiplying agents), adequately instructed by ophthalmologists.
3) The few who had questions reported them to be linked to the application of the visual acuity test, the obtained results and the completion of forms.

4) Among the difficulties mentioned concerning the campaign, we should mention "transportation (locomotion)" of the children to the site of the ophthalmologic examination, the "scheduling of the ophthalmologic visit", the delay in the delivery of glasses and the fact that the examination was limited to children in the 1 st grade. Some suggestions to solve these difficulties have been pointed out: ophthalmologic examination conducted at sites close to the schools; communitarian efforts and search for partners in order to provide free transportation, together with better orientation of the school administration personnel, improving the scheduling of examinations and the transmission of corresponding information to the parents.

5) Positive aspects mentioned were: better learning performance and fewer dropouts from school.

6) Such programs have difficulties to be executed and will always require adjustments. They should be continuously improved. To cancel such a relevant program would be a major step backwards in terms of the social and cognitive development of these children.

\section{Suggestions}

- Increase the number of meetings with multiplying agents, to allow for better training of teachers.

- Get parents and the community involved in the development of the project.

- Acknowledgement of the teachers' contribution through positive attitudes, such as: awarding a merit certificate for the accomplished work and offering a free ophthalmologic examination to teachers directly involved with the campaign.

\section{RESUMO}

Objetivos: 1) Verificar opiniões de professores envolvidos na triagem visual e encaminhamento para exame oftalmológico de escolares na "Campanha Nacional de Prevenção e Reabilitação Visual Olho no Olho”. 2) Identificar a percepção dos professores em relação ao treinamento fornecido para execução da campanha. Métodos: Realizou-se estudo descritivo de dados registrados provenientes da aplicação de questionário a 1.517 professores da primeira série do Ensino Fundamental do sistema público de ensino de 27 Estados brasileiros. Foram investigados: recebimento de orientações, uso de manuais e vídeos ilustrativos, orientações fornecidas, dificuldades, dúvidas e avaliação geral da campanha. Resultados: 82,0\% dos educadores declararam ter recebido orientações e $92,0 \%$ terem lido o "Manual de Orientação ao Professor". Dos que receberam orientações, $47,0 \%$ declararam que foram ministradas por funcionários da escola; $30,0 \%$ por profissionais do serviço de 
Saúde e $23,0 \%$ por oftalmologistas. Na auto-avaliação de desempenho, 58,0\% não apontaram dificuldades. $32,0 \%$ relataram dúvidas em relação às atividades da campanha e o profissional mais procurado para solucioná-las foi o profissional da Secretaria da Educação $(38,0 \%)$, seguido do diretor da escola $(20,0 \%)$. Conclusões: A maioria dos professores considerouse bem orientado e treinado para participar da campanha. O treinamento aos professores foi fornecido por profissionais administrativos após orientação de oftalmologistas ("efeito multiplicador") e o pequeno percentual com dúvidas indica sua validade. Foram relatadas preocupações com o aviso para realização do exame oftalmológico, o transporte dos escolares e a entrega dos óculos.

Descritores: Saúde ocular; Saúde escolar; Serviços de saúde escolar; Promoção da saúde; Educação em saúde; Conhecimentos, atitudes e prática em saúde; Oftalmopatias/diagnóstico; Oftalmopatias/prevenção \& controle; Erros de refração/ diagnóstico

\section{REFERENCES}

1. Krueguer EA. Prevenção da cegueira na infância. Planejamento. Arq Bras Oftalmol. 1969;32(1):23-5.

2. Toledo SA. Cooperação da escola primária no combate ao tracoma. São Paulo: Revista Os Tribunais; 1938. p.134-8.

3. Castro RS. Correção óptica em escolares e condições de uso dos óculos. [tese]. Campinas: Faculdade de Ciências Médicas da Universidade Estadual de Campinas; 2001.

4. Kara-José N, Ferrarini ML, Temporini ER. Avaliação do desenvolvimento do plano de oftalmologia sanitária escolar em três anos de sua aplicação no Estado de São Paulo. Arq Bras Oftalmol. 1977;40(1):9-15.
5. Conselho Brasileiro de Oftalmologia: "60 anos de CBO"; livro demonstrativo; gestão 1999-2001. São Paulo:CBO; 2001.

6. Alves MR, Kara-José N. Manual de Orientação ao professor. Campanha Nacional de Reabilitação Visual "Olho no Olho". São Paulo: Impresa Oficial; 1998.

7. Oliveira RCS, José NK, Arieta CEL. Manual da boa visão do escolar: solucionando dúvidas sobre o olho e a visão. São Paulo; Brasília: Conselho Regional de Oftalmologia: Ministério da Educação; 2001.

8. Conselho Brasileiro de Oftalmologia. Ofício - CBO da Campanha "Olho no Olho". Quadro analítico dos resultados finais e parciais 2001. São Paulo: CBO; 2001.

9. José NK, organizador. Prevenção da cegueira por catarata. Campinas: Unicamp; 1996. p.55-80.

10. Kara-José N, Gonçalves ER, Carvalho RS, organizadores. Olho no olho: campanha nacional de prevenção à cegueira e reabilitação visual do escolar. Rio de Janeiro: Cultura Médica; 2006.

11. Temporini ER, Kara-José N, Rigolizzo HB. Envolvimento de pessoal da comunidade em projeto de detecção de ambliopia em pré-escolares. Arq Bras Oftalmol. 1983;46(3):85-9.

12. Alves MR, Temporini ER, Kara-José N. Atendimento oftalmológico de escolares do sistema público de ensino no município de São Paulo: aspectos médico-sociais. Arq Bras Oftalmol. 2000;63(5):359-63.

13. Russ HHA, Temporini ER, Kara-José N. Impacto da Campanha Olho no Olho em escolas de ensino fundamental: percepção do pessoal de ensino. Arq Bras Oftalmol. 2004;67(2):311-21

14. Temporini ER, Kara-José N, Taiar A, Ferrarini ML. Validade da aferição da acuidade visual realizada pelo professor em escolares de $1^{\text {a }}$ a $4^{\text {a }}$ séries de primeiro grau de uma escola pública do município de São Paulo, Brasil. Rev Saúde Pública. 1977;11:229-37.

15. Conselho Brasileiro de Oftalmologia. Ofício CBO: "Orientações Gerais aos Coordenadores Estaduais, Municipais e demais participantes da Campanha"; 1998. São Paulo: CBO; 1998.

16. Temporini ER. Percepção de professores do sistema de ensino do Estado de São Paulo sobre seu preparo em saúde do escolar. Rev Saúde Pública. 1988; 22(5):411-21.

17. Cavalcante SM, José NK, Temporini ER. Percepção de pais de escolares da $1^{\text {a }}$ série do ensino fundamental a respeito da campanha Olho no Olho 2000, na cidade de Maceió-Alagoas. Arq Bras Oftalmol. 2004;67(1):87-91.

18. Abud AB, Ottaiano JAA. Aspectos socioeconômicos que influenciam no comparecimento ao exame oftalmológico de escolares com alterações visuais. Arq Bras Oftalmol. 2004;67(5):773-9.

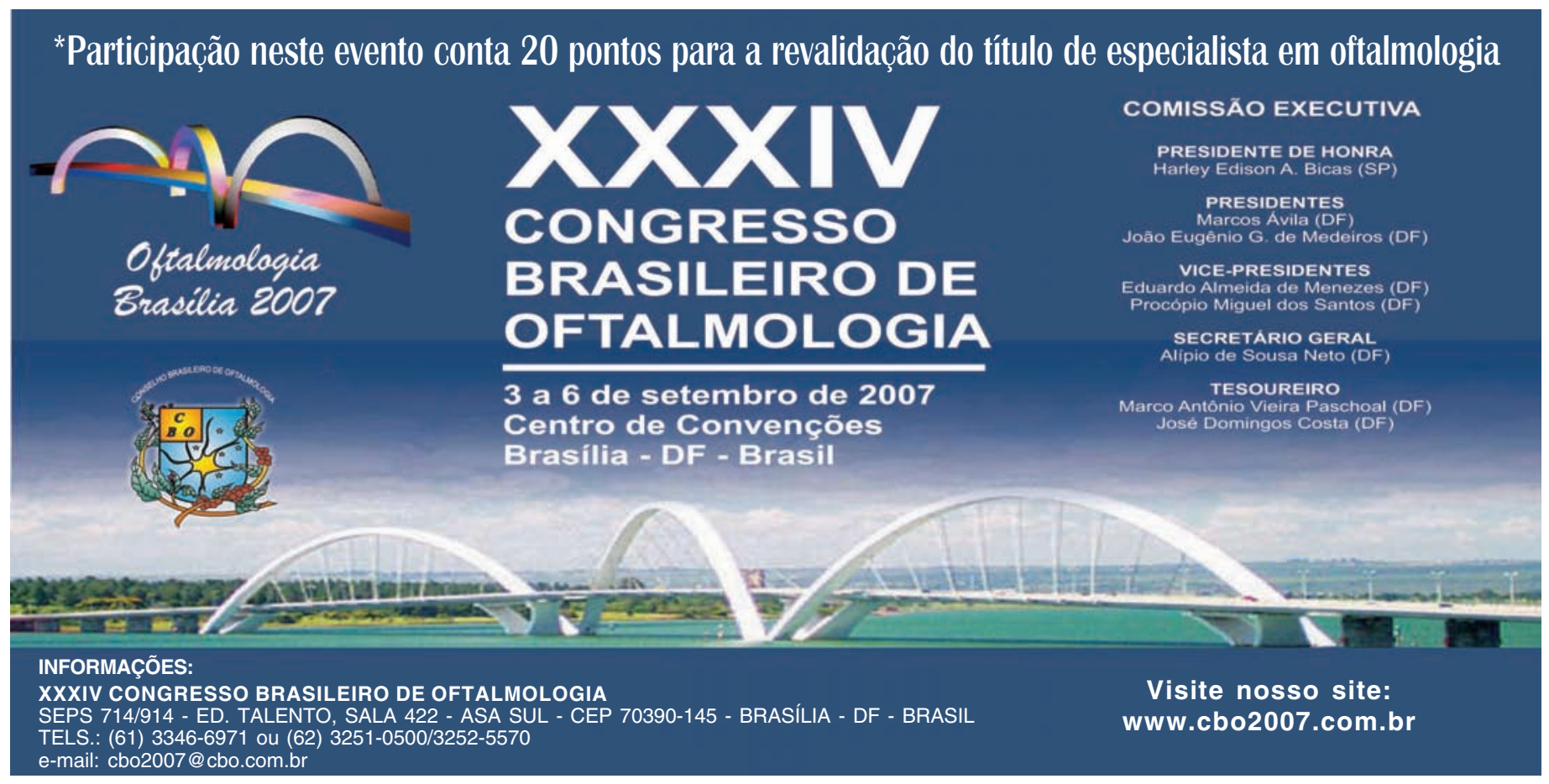

